cil's study of university research. Several comments were critical of the current situation on university campuses. For example, Bromley indicated that "university/industry partnerships are more talk than reality and usually depend on the presence of a particular individual rather than on an institutional philosophy." He also indicated that the department structures at most universities are a "loose coalition of feudal fiefdoms" and mitigate against implementing interdisciplinary research programs. Bromley contended that the U.S. is generally in front technically but clearly trailing in focus areas, such as optics in France and ultrapure materials in the USSR. His panel recommended a ten-year, ten-billion-dollar program to fund facilities "catch-up" on university campuses, funded with new money and not simply a tax on existing research dollars. Half of the funds would come from sources other than the federal government.

McClelland drew several analogies to highlight the contention that the classical disciplines on university campuses are anachronistic. Mentioning the last century's Latin and Greek core curricula which dominated for 100 years, he pointed to university chemistry and physics departments, indicating that by the next century, they may have gone the way of Latin and Greek. His evidence for this contention rests on student matriculation trends in chemistry and physics programs compared with those in engineering and the biological sciences. Describing the rejection by older departments on university campuses of the newer branches of their own disciplines, he illustrated "scholarly suicide," such as the English departments' rejection of journalism, the mathematics departments' rejection of statistics and of computer and information sciences, and the chemistry departments' rejection of chemical process engineering. All these trends mitigate in favor of the disappearance of the older core science curricula. He pointed out that $85 \%$ of the research at duPont, his home institution, is in polymers and is not represented in the chemistry departments of major, high-prestige universities. One solution he offered is the introduction of dynamic research areas at the high school level to induce new college students to demand instruction in the more exciting forefront areas.

Braben compared the differences in the criteria used by the Venture Research Unit (B.P. International, Ltd.) in selecting projects and principal investigators for funding with those used by the normal national funding organizations. In each instance, the national funding organizations emphasized disciplinary or problemoriented categories, invoking criteria which would produce caution and reduce serendipity in their funded research. The Venture Research Unit approach rests on identifying the appropriate investigators and essentially giving them their heads.

Malcolm decried the situation in the education of science teachers, pointing to the effect of eliminating the undergraduate education degree, particularly for science educators. Her conclusion, a significant one, was that the buck will now stop with the science departments rather than the education departments at the undergraduate level since it will be their responsibility to supply to the graduate schools students who are very well founded in their respective disciplines; i.e., "they can no longer blame the education departments for the poor quality of science education in the schools.

The 1986 meeting of the AIP Corporate Associates was attended by several MRS officers: Gordon Pike, 1986 MRS President; Clifton Draper, 1986 Treasurer; John Baglin, 1986 Second Vice President; and Elton Kaufmann, 1986 Immediate Past President. Before the meeting, Pike had an opportunity to discuss with the AIP Governing Board and its new chairman, Prof. Hans Frauenfelder, issues of mutual concern to AIP and MRS.

\section{MRS BULLETIN Expands to Eight Issues in 1987}

Elton N. Kaufmann, chairman of the MRS BULLETIN Editorial Board, has announced that the MRS BULLETIN will publish a total of eight issues in 1987 to accommodate the recent rapid growth in technical articles and news. The BULLETIN, which begins its twelfth year of publication and was previously published every other month, has expanded its coverage of news and scientific developments in 1986 in parallel to the Society's farreaching interests and activities.

"The BULLETIN is receiving wide attention in the United States and internationally, from both the scientific community and government leaders. It is becoming an important source of information on trends and developments in materials research and education, and serves as a voice for the materials profession on issues such as national and international priorities and policies," Kaufmann said. "The BULLETIN will continue to grow as a forum for the exchange of ideas and opinion from the diverse international scientific community."

During 1987, special issues will focus on recent developments in ion beams, glasses, materials characterization, ceramics, education, and polymers. Other regular features will also continue to expand: editorials, news, new products, the "Up Close" series on materials laboratories, government issues, book reviews, and more. Many solicited and contributed articles are now under preparation for up- coming issues, and new ideas and topics are always welcome.

If you would like to contribute to the MRS BULLETIN or offer suggestions on areas you would like to see covered, contact Elton N. Kaufmann, Lawrence Livermore National Laboratory, P.O. Box 808 L-217, Livermore, CA 94550, telephone (415) 423-2640; or Gail Oare, Materials Research Society, 9800 McKnight Road, Suite 327, Pittsburgh, PA 15237, telephone (412) 367-3036.

\section{Von Hippel Award Nominations Sought}

\section{The Society's \\ Most Prestigious Honor}

The MRS Awards Committee, chaired by Past President Gordon Pike, has announced that nominations are being accepted for the Society's highest award, the Von Hippel Award of the Materials Research Society. The Award is an international hallmark of excellence in the field of materials research, numbering nine prominent materials scientists as past recipients.

The Award is named for the Emeritus Professor of the Massachusetts Institute of Technology, Arthur von Hippel, whose laboratory pioneered the collaborative, interdisciplinary research that subsequently has taken the identity of "materials science." It recognizes those qualities most prized by materials scientists - brilliance and originality of intellect, combined with vision that transcends conventional scientific disciplines. The Award is presented annually by the Society at its Fall Meeting.

Past recipients of the Award are

Prof. Arthur von Hippel

Dr. William O. Baker

Prof. David Turnbull

Prof. W. Conyers Herring

Prof. James W. Mayer

Prof. Clarence M. Zener

Prof. Sir Peter B. Hirsch

Dr. Walter L. Brown

Dr. John W. Cahn

Prof. Minko Balkanski

The recipient is selected by majority vote of the MRS Council from a slate of candidates that is prepared by the Awards Committee. Nominations should be made to the MRS Awards Committee. Names put into nomination are, in accordance with MRS Bylaws, considered active for three years. Nominations must be made using the Von Hippel Award Nomination Form and should be accompanied by supporting documentation.

Nominations should be sent to: Gordon E. Pike, Sandia National Laboratories, Division 1815, Albuquerque, NM 87185.

MIRS 


\section{MRIS \\ VON HIPPEL AWARD of the Materials Research Society}

\section{Nomination Summary Form}

This form is to be used to cover all documentation submitted in support of nominations for the VON HIPPEL AWARD of the Materials Research Society. Additional copies may be obtained from MRS Headquarters, 9800 McKnight Road, Suite 327, Pittsburgh, PA 15237; telephone (412) 367-3003.

Full Name of Candidate:

Position and Affiliation (present and recent past):

Address and Telephone:

Education:

List of supporting documents submitted with this nomination:

\section{Qualification of Nominees}

Potential nominees for the Materials Research Society's Von Hippel Award must have outstanding scientific credentials, their scientific work must have had a real impact on materials research, and they must have demonstrated an interdisciplinary approach to materials research. The scientific background of the nominee is of no consideration except that the work must have been in areas commonly associated with materials research. The nominee does not have to be a member of the Materials Research Society and nominees of any nationality are eligible. It is not necessary for the nominee to have won awards from other societies or technical groups. One of our objectives is to identify those individuals who have reached the stage in their careers when they will be first considered for major awards.

II. Preparation of Nomination Package

It is the responsibility of the nominator to prepare a nomination package for the candidate according to the following instructions. The nominator should supply a statement of the candidate's suitability for the Von Hippel Award in which the following topics should be addressed in separate paragraphs:

(1) interdisciplinary character of candidate's work.

(2) manner in which candidate's work spans basic and applied science.

(3) impact of candidate's work within and outside their immediate professional field.

The nominator may add any other pertinent information. Whenever possible, the nominator's statement should cite evidence rather than opinion or intuition. As part of the package, the nominator must arrange for at least three distinguished scientists to send letters supporting the nomination which also address the three items above. Additional supporting documents should include publication, patent, and award listings. While it is not essential to provide a complete list of these items, the nominator should indicate an approximate number for each and must supply a list of the most important papers and books published by the nominee.

A nomination for the Von Hippel Award remains under consideration for three years, so individuals who are nominated in 1987 will remain under consideration through 1989. In preparing nominations, please bear in mind that the nominees for this award should have made outstanding contributions to our profession. The nomination package should truly reflect the accomplishments and the stature of the individual-a poorly prepared nomination for an outstanding individual is a disservice to that person.

III. Selection of Von Hippel Award Recipient

The recipient of the Von Hippel Award is determined by a vote of the MRS Council.

IV. Deadline for Submission of Nominations

To be considered for the 1987 Award, the nomination must be submitted to Gordon Pike, Chairman of the Awards Committee, by July 1, 1987. His address is Sandia National Laboratories, Division 1815, Albuquerque, NM 87185. 